\title{
Heterogeneity in a communal cattle-farming system in a zone endemic for foot and mouth disease in South Africa
}

\author{
Ockert Louis van Schalkwyk, ${ }^{1,2}$ Eva M. De Clercq, ${ }^{3,4}$ Claudia De Pus, ${ }^{5}$ Guy Hendrickx, ${ }^{3}$ \\ Peter van den Bossche, ${ }^{5}$ Darryn L. Knobel ${ }^{6,7}$ \\ ${ }^{1}$ Centre for Veterinary Wildlife Studies, University of Pretoria, Onderstepoort; ${ }^{2}$ Office of the \\ State Veterinarian, Skukuza, South Africa; ${ }^{3}$ Avia-GIS, Zoersel; ${ }^{4}$ Research Fellow FNRS, Earth \\ and Life Institute, Université Catholique de Louvain, Louvain-la-Neuve; ${ }^{5}$ Institute of Tropical \\ Medicine, Antwerpen, Belgium; ${ }^{6}$ Department of Veterinary Tropical Diseases, University of \\ Pretoria, Onderstepoort, South Africa; ${ }^{7}$ Center for Conservation Medicine and Ecosystem \\ Health, Ross University School of Veterinary Medicine, Basseterre, St Kitts and Nevis
}

\begin{abstract}
In South Africa, communal livestock farming is predominant in the foot and mouth disease control zone adjacent to the Greater Kruger National Park (KNP), where infected African buffaloes are common.
\end{abstract}

\footnotetext{
Correspondence: Ockert Louis van Schalkwyk, Office of the State Veterinarian, P0 Box 12, Skukuza 1350, South Africa.

Tel. +27.013.735.5641.

E-mail: lvs@vodamail.co.za
}

Key words: Communal livestock farming; Wildlife-livestock interface; Disease control; Spatial heterogeneity; South Africa.

Remembrance: we would like to dedicate this paper to Prof. Peter Van den Bossche who was a friend and colleague and who tragically left us before this paper was published. We all knew Peter from different angles and found great pleasure in working with him. He was very supportive of this research and very interested in how outcomes may help improve livestock management at the wildlife-livestock interface.

Acknowledgements: this work was funded by the Belgian Science Policy Office (Belspo) STEREO II Programme, Project SR/00/102: EPISTIS. The research was also supported by the Peace Parks Foundation. The authors would like to thank the State Veterinary Services of Mpumalanga and Limpopo Provinces in South Africa for their assistance in accessing archived livestock registers. General statistical advice received from Drs. Dirk Berkvens and Luigi Sedda is greatly appreciated.

Received for publication: 26 February 2015.

Revision received: 23 July 2015.

Accepted for publication: 8 August 2015.

(C) Copyright O.L. van Schalkwyk et al., 2016

Licensee PAGEPress, Italy

Geospatial Health 2016; 11:338

doi:10.4081/gh.2016.338

This article is distributed under the terms of the Creative Commons Attribution Noncommercial License (CC BY-NC 4.0) which permits any noncommercial use, distribution, and reproduction in any medium, provided the original author(s) and source are credited.
During routine veterinary inspections of cattle in this area, a large amount of production and demographic parameters were being recorded. These data were collated for a five-year period (2003-2007) in three study sites to better understand the temporal dynamics and spatial heterogeneity in this system. A decreasing gradient from South to North with respect to both human and cattle population densities was observed. Rainfall and human population density alone could explain $71 \%$ of the variation in cattle density. Northern and central sites showed an overall decrease in total cattle numbers (15.1 and $2.9 \%$, respectively), whereas a $28.6 \%$ increase was recorded in the South. The number of cattle owners in relation to cattle numbers remained stable during the study period. Only $4.0 \%$ of households in the South own cattle, compared to 13.7 and $12.7 \%$ in the North and Centre. The overall annual calving rate was $23.8 \%$. Annual mortality rates ranged from 2.4 to $3.2 \%$. Low calf mortality (2.1\%) was recorded in the North compared to the South (11.6\%). Annual off-take in the form of slaughter averaged $0.2,11.7$, and $11.0 \%$ in the North, Central and South sites, respectively. These figures provide valuable baseline data and demonstrate considerable spatial heterogeneity in cattle demography and production at this wildlife-livestock interface, which should be taken into consideration when performing disease risk assessments or designing disease control systems.

\section{Introduction}

A large area next to the Kruger National Park (KNP) and its adjoining private and provincial nature reserves (APNR) in South Africa, is used for communal farming of both livestock and crops. Although the World Animal Health Organisation (OIE) considers South Africa to be free from the foot and mouth disease (FMD) in areas where vaccination is practised, the KNP and APNR are endemic for FMD (Brückner et al., 2002; Vosloo et al., 2002; Scoones et al., 2010), and this is due to the presence of the reservoir host of the disease, the African buffalo (Syncerus caffer) (Vosloo et al., 2006). To this end, a fence was erected around the KNP in the 1960s (Joubert, 2007; Scoones et al., 2010), and compulsory, weekly cattle inspections and bi- to tri-annual vaccination against FMD takes place at government livestock inspection points (IPs) within the area directly adjacent to the infected zone (the so-called protection zone with vaccination). Livestock in the remainder of the protection zone (protection zone without vaccina- 
tion) are inspected every fortnight and are not vaccinated. In addition, strict movement controls, enforced through a movement permit system, enable traceability of animal movements to, from and between IPs inside the protection zone (Brückner et al., 2002; Scoones et al., 2010; Vosloo et al., 2002). This regular monitoring presents a unique opportunity to gain insight into some of the basic production and demographic parameters of this communally farmed livestock system. Land in these areas remains public property and is managed under communal tenure. Communal farming is an inherently different agricultural system to commercial farming enterprises (Behnke Jr., 1985; Giannecchini et al., 2007) and direct comparisons are not advisable (Abel, 1997; Swanepoel et al., 2000). Nevertheless, productivity comparisons of these systems have been widely attempted, with the finding that, on a per animal basis, communal farming compares poorly to commercial enterprises, but on a per hectare basis, it performs as well, if not better (Barrett, 1991; Shackleton et al., 2005).

Close to three quarters of the income of subsistence farming households in South Africa is generated by wages and salaries, often earned through jobs in urban centres, or social grants unrelated to the farming operation, with very little income derived directly from crops or livestock (Kirsten and Moldenhauer, 2006; Goqwana et al., 2008). The benefits of livestock, cattle in particular, are not restricted by their financial value, and include various direct-use benefits such as meat, milk, manure, draught power, transport, and hides (Barrett, 1991; Scoones, 1992b; Swanepoel et al., 2000; Shackleton et al., 2005, Dovie et al., 2006). Much of the financial value of cattle is locked up as potential value, such that the animals act as a living savings account (Randolph et al., 2007; Shackleton et al., 2001). Livestock have the further advantage over crops that they can be utilised at any time during the year (Vandamme et al., 2010). Although a number of studies have been conducted within the communal livestock farming area along the western boundary of the KNP (Swanepoel et al., 2000; Dovie et al., 2003, 2006; Shackleton et al., 2005; Nthakheni, 2006; Stroebel et al., 2008, 2011), none of these considered the heterogeneity within the larger area explicitly, since they mainly focused on individual communities.

This paper aims to provide quantitative data on the heterogeneity and spatio-temporal trends of the cattle population of roughly 350,000 animals found in the control zone described. It was felt that baseline demographic information and population trends could aid disease risk assessments, surveillance and control in the region, activities which currently do not explicitly consider such heterogeneities.

\section{Materials and Methods}

\section{Study sites}

The study was conducted in three sites (North, Centre and South) along the western boundary of the KNP and APNR. Figure 1 shows the location of these sites, which were originally selected based on a combination of areas perceived by local experts to be at high risk of FMD outbreaks (due to African buffaloes straying from game reserves and coming in contact with cattle) as well as the perceived differences between the sites with regard to land use, population density and general environmental conditions.

All three sites are situated in the Lowveld region of northeastern South Africa, a low altitude area characterised by hot summers, during which the peak rainfall occurs (November to February), and mild, dry winters. Prior to 1994, these sites formed part of the former Venda and
Gazankulu homeland states. The three study sites comprised 38 IPs in total (North: 10; Centre: 12; South: 16), all of which are in the FMD protection zone with vaccination.

\section{Census data}

Data on the number of people and households were obtained from the 2001 national census (Statistics South Africa, 2001). Numbers per IP were derived using the centroids of census polygons falling inside the IP boundaries as determined by the density analyses.

\section{Livestock data}

During the compulsory weekly inspection of cattle for FMD, cattle population data are collected by animal health technicians of the provincial state veterinary services. These data are kept in a livestock register on a per owner basis and aggregated per month at an IP level. Data for this study was retrieved from routine monthly aggregate hard copy reports of the livestock register and entered into an electronic database for the period January 2003 to December 2007 (Table 1).

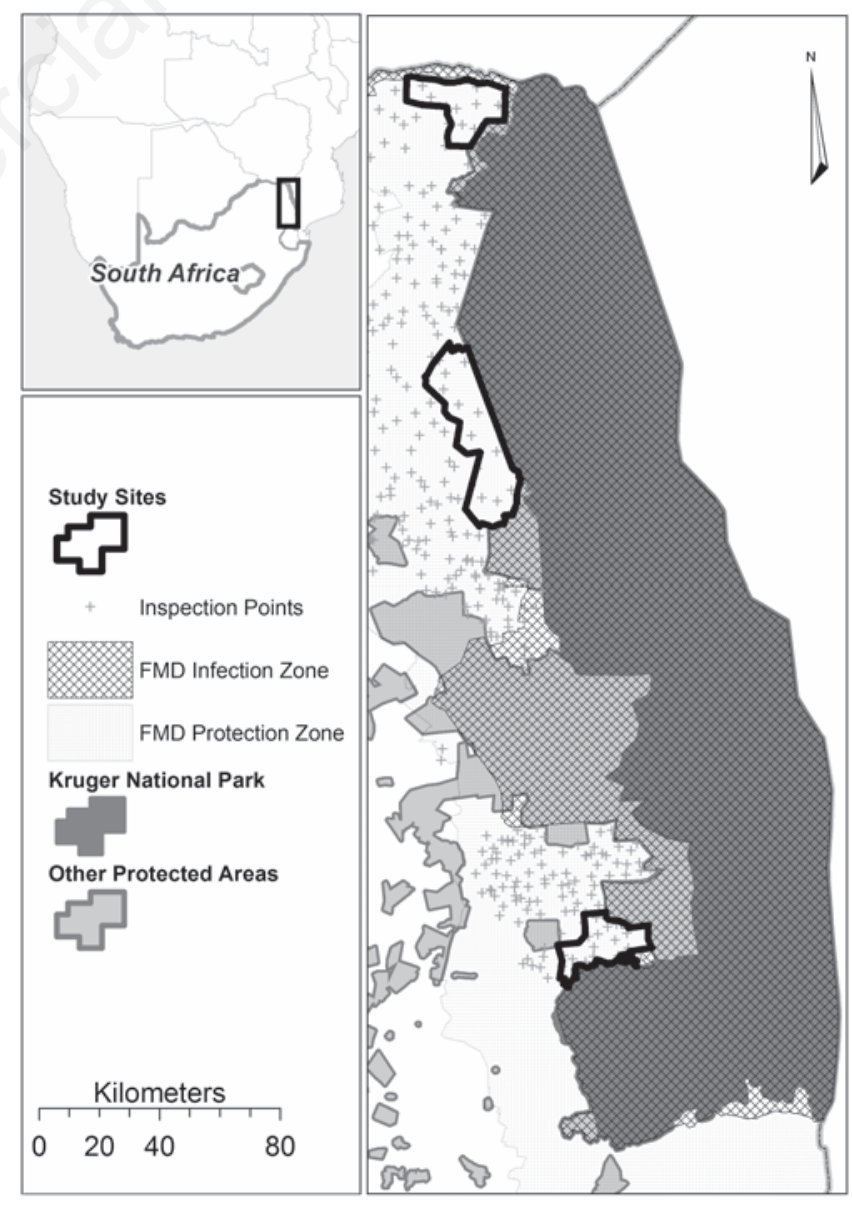

Figure 1. Location of study sites. 


\section{Derived variables}

\section{Calving rate}

The livestock register data did not contain detailed information on the age and gender composition of the cattle population (other than calf numbers) and therefore the calving rate reported represents calves born as a proportion of the total cattle population, rather than just cows, as is the convention.

\section{Conception time series}

Based on the calving data, a conception time series was created using a nine-month gestation period lag.

\section{Net permit movements}

The net movement of animals by means of permits was calculated by subtracting outgoing permits from incoming permits at each IP. Negative permit figures therefore reflect a net movement away from an IP.

\section{Off-take}

Since some of the data only contained net permit movements, we could not separate incoming and outgoing permits to work out crude off-take/import rates. Hence, we only calculated net off-take, being the sum of net permits movements and slaughter per year in relation to the median number of cattle at a particular IP within the same year.

\section{Own/local consumption}

Total number of cattle slaughtered per year in relation to the median number of owners at that IP, during the same year.

\section{Density}

Areas used for the calculation of cattle densities in the southern site were based on historic farm boundaries (so-called parent farms). No such farm boundaries existed for the northern and central sites, so areas here were based on Thiessen polygons derived from the location of the IPs. Thiessen polygons define the area around sample points, so that any location within each polygon is closest to its sample point (ESRI, 2009). The choice of area delineation was confirmed by cattle tracking data collected in a related study in all three sites as described by Van Schalkwyk (2015). Where subdivisions of IPs existed (e.g. where two groups visited the same IP location, but bearing a different IP designation - e.g. Ireagh A and Ireagh B), cattle numbers were aggregated for density calculations.

\section{Cattle/owner ratio}

Since these data were aggregated per IP, we did not have numbers at the owner level. The cattle to owner ratio was thus used as a proxy for the mean herd size at a given IP location, even though a large amount of the variability in individual herd size was inherently lost (Behnke Jr., 1987; Swanepoel et al., 2000; Mapiye et al., 2009a).

\section{Proportion of households keeping cattle}

The number of cattle owners divided by the census households in the area of the IP can be used as an indication of the proportion of census households keeping cattle (making the assumption that no more than one cattle owner resides in each household).

\section{Missing data}

In the three study sites (North, Centre and South), 68.8, 84.3 and $71.6 \%$ of the monthly records, respectively, were complete for the study period (74.9\% overall). Missing data points were imputed by linear interpolation and by carrying forward or backward the closest observation where missing values were at the beginning or end of a time series. Missing net permit movements for the current month $\left(P_{n e t, t}\right)$ were calculated after interpolation of the total number of cattle $\left(N_{t}\right)$ in the current month $(t)$, the number of cattle in the previous month $\left(N_{t}\right.$ $\left.{ }_{1}\right)$, the births in current month $\left(B_{t}\right)$, the mortality in current month $\left(M_{t}\right)$ and the number of animals locally sold/slaughtered in the current month $\left(S_{t}\right)$ using the following formula:

$$
P_{n e t, t=} N_{t}+B_{t}-M_{t}-S_{t}-N_{t-1}
$$

Linear interpolation had no influence on the variance of the final dataset. Two IPs opened and one closed during the study period; data for the periods when these IPs did not function were not imputed and instead retained as true missing values.

\section{Environmental data}

The normalised difference vegetation index (NDVI) is a ratio of the

Table 1. Attributes recorded per livestock inspection point from the monthly aggregates of the livestock register for each of the study sites.

\begin{tabular}{ll} 
Attribute & \multicolumn{1}{c}{$\begin{array}{c}\text { Remarks } \\
\text { Number of cattle owned }\end{array}$} \\
Number of calves in herd & Number of cattle registered per IP \\
\hline Number of calves born since last inspection & - \\
Mortality since last inspection & No cause of death recorded. It also includes stock theft \\
\hline Calf mortality since last inspection & No cause of death recorded. It also includes stock theft \\
Local sales and animals slaughtered & $\begin{array}{l}\text { Home slaughter for own consumption or selling to, and slaughter by, } \\
\text { a local butcher within the same IP area, which requires no movement permit }\end{array}$ \\
\hline Permits & $\begin{array}{l}\text { It could include permits for buying/selling, giving/receiving or borrowing/lending of livestock to/ } \\
\text { from someone outside the IP area. } \\
\text { No registered abattoirs/feedlots exist in any of the study sites, } \\
\text { and any commercial sale to abattoirs/feedlots would thus also fall under permit movements, } \\
\text { rather than local sales and slaughtered. }\end{array}$ \\
\hline
\end{tabular}

\footnotetext{
IP, inspection point.
} 
red and near infrared reflectance as measured by the Moderate Resolution Imaging Spectroradiometer (MODIS) and is generally used to assess the health and density of vegetation (Carroll et al., 2004; Klingseisen et al., 2013). NDVI data from 2001 to 2008 with a 16-day interval were obtained from the United States Geological Survey (2013) and de-noised using a cubic spline interpolation (Scharlemann et al., 2008).

Land cover data at the $30 \mathrm{~m}$ resolution (GeoterraImage, 2008) derived from Landsat 5 (http://landsat.gsfc.nasa.gov/?P=3180) was recategorised into four categories: i) areas potentially suitable as grazing areas, i.e. open woodland, open sparse bush-land, open sparse grassland and bush-land and thicket (here called Grazing); ii) urban areas (here called Urban); iii) non-wet bare areas, which have low potential for grazing (here called Bare); and iv) dry-land subsistence cultivation areas (here called Subsistence). Rainfall per IP was based on its nearest weather station and aggregated per month from daily data obtained from the South African Weather Service for the period 1998-2008.

The year refers here to the 12-month period from 1 July through 30 June. This was used in the analysis of the livestock data rather than calendar years to avoid splitting rainy and/or calving seasons, which peak around the beginning/end of the calendar year.

\section{Statistical analysis}

General statistical analyses were conducted using R (R Core Team, 2013) and Microsoft Excel 2007 (Microsoft Corporation), while spatial analyses were done using IDRISI Andes (Eastman, 2006), ArcGIS, version 9.3.1 (ESRI, 2009) and Hawth's Analysis Tools for ArcGIS (Beyer, 2004). Space-time cluster analysis was done using a discrete Poisson space-time scan statistic in the SatScan software package, version
9.1.1 (Kulldorff, 1997). Figures reported in text refer to the median followed by the interquartile range in brackets, unless otherwise specified.

\section{Time series decomposition}

This was used to split time series values for livestock data into i) a trend component (calculated by a moving average: symmetric window with equal weights); ii) a repeating pattern component within each year (also known as the seasonal component), which averages each point in the time series over the entire period, after trend removal; and iii) the remainder (noise) (decompose function of the R Stats package; Cowpertwait and Metcalfe, 2009).

\section{Index}

The Gini index was used to assess seasonality in birth, mortality and off-take. It measures statistical dispersion in a dataset, and can be seen as a quantitative measure of clustering in data (temporal in this case). A Gini index of zero signifies perfect equality, e.g. all months having equal calving frequencies, compared to one, where all births would occur in a single month (Gastwirth, 1972; Lee, 1996).

\section{Cross-correlation}

The cross-correlation function in the Stats package of R was used to compute the correlation between two univariate time series spanning the same period, each at a different lag period. Where necessary, time series were log transformed. Since we were also interested in correlation of the seasonal components of these time series, seasonal components in the time series were not removed (Cowpertwait and Metcalfe, 2009).

Table 2. Overview of the biophysical and demographic characteristics of the study sites.

\begin{tabular}{|c|c|c|c|}
\hline & \multicolumn{3}{|c|}{ Site } \\
\hline & North & Central & South \\
\hline Area $\left(\mathrm{km}^{2}\right)$ & 405 & 965 & 321 \\
\hline Mean elevation $(m)^{*}$ & 366 & 403 & 413 \\
\hline Mean annual rainfall (range) $(\mathrm{mm})^{\circ}$ & $310(200-400)$ & $520(400-700)$ & $680(550-850)$ \\
\hline Mean temperature (range) $\left({ }^{\circ} \mathrm{C}\right)^{\circ}$ & $23.5(10.2-34.5)$ & $22.2(8.8-32.8)$ & $21.5(8.1-31.5)$ \\
\hline Population density (people/km²) $)^{\#}$ & 22.4 & 62.0 & 565.7 \\
\hline Household density (households/km²) & 5.5 & 13.3 & 122.5 \\
\hline
\end{tabular}

*Aster 30m Digital Elevation Model (2009) [Ministry of Economy, Trade, and Industry (METI) of Japan and the United States National Aeronautics and Space Administration (NASA)]; ${ }^{\circ}$ Hijmans et al. (2005); "HStatistics South Africa (2001).

Table 3. Predominant land cover of the three study sites (\%).

\begin{tabular}{lcccc} 
Study site & & \multicolumn{3}{c}{ Land cover } \\
& Graving & Urban & Bare & Sulbsistence cultivation \\
North & 91.4 & 0.8 & 3.1 & 3.9 \\
Central & 78.4 & 4.0 & 4.8 & 11.1 \\
\hline South & 43.9 & 16.7 & 10.3 & 1.6 \\
\hline
\end{tabular}




\section{Results}

\section{Land use}

Table 2 gives an overview of the biophysical and demographic characteristics of the study sites. A strong, latitudinal gradient in human population densities can be observed, with the lowest densities occurring in the North. This gradient is also reflected in the land cover (Table 3) of the three study sites. The relatively high proportion of subsistence cultivation found in the southern site was not proportional to the increase in population, with the area of subsistence cultivation per household higher in the northern [1.10 ha (0.57-2.16)] and central site [0.90 ha (0.54-1.33)] than in the South [0.24 ha (0.17$0.30)$ ]. Despite subsistence cultivation areas providing potential seasonal fodder (Herrero et al., 2010; Rocha et al., 1991) and bare areas being lush green with annual grass and herbaceous plants in the early rainy season (personal observation), they were not considered as potential grazing areas due to the inconsistent nature in this respect. Less than half (43.9\%) of the southern site could be regarded as potential grazing area, compared to $91.4 \%$ in the northern area and $78.4 \%$ in the centre.

\section{Cattle numbers and densities}

Total cattle numbers for each study site are shown in Figure 2 with the dashed line depicting the temporal trend after removal of seasonal fluctuations through time series decomposition of the data.
The northern and central sites showed an overall decrease of 15.1 and $2.9 \%$, respectively, in total cattle numbers over the five-year study period, whereas a $28.6 \%$ increase in the number of cattle was recorded in the South, corresponding to an annual growth rate of $5.15 \%$. Notwithstanding, fluctuations of $35-42 \%$ were recorded in all threestudy sites over the study period.

Time series decomposition revealed a seasonal pattern in the cattle numbers of all three study sites. The fluctuation ascribed to seasonal variation, evaluated as a percentage of the median number of cattle in the study area, showed that seasonal variation was only responsible for $4-6 \%$ of the fluctuation in the northern and central sites, and less than two percent in the South.

The median proportion of calves in the cattle population in the other two sites differed significantly from the central site, i.e. $19.37 \%$ (14.16$23.40)$ vs $11.91 \%$ (8.21-16.98) and $10.71 \%$ (6.95-16.53) in the northern and southern sites, respectively (Kruskal-Wallis rank sum test; $\mathrm{P}<0.01$ ).

The median cattle density for the northern, central and southern sites during the study period was 11.6 (9.4-14.2), 18.6 (15.1-22.4) and 32.7 (27.5-37.1) animals per $\mathrm{km}^{2}$, respectively. A combination of human population density and annual rainfall could explain $71 \%$ of the variation in cattle density recorded per IP $\left(\mathrm{R}^{2}=0.71 ; \mathrm{P}<0.01\right)$. When considering all IPs across the three study sites, a $68.2 \%$ correlation between the cattle density and area of subsistence cultivation per household was evident $(\mathrm{t}=12.56, \mathrm{P}<0.01)$. Within each study site, however, this correlation was less pronounced, and it was only signif-

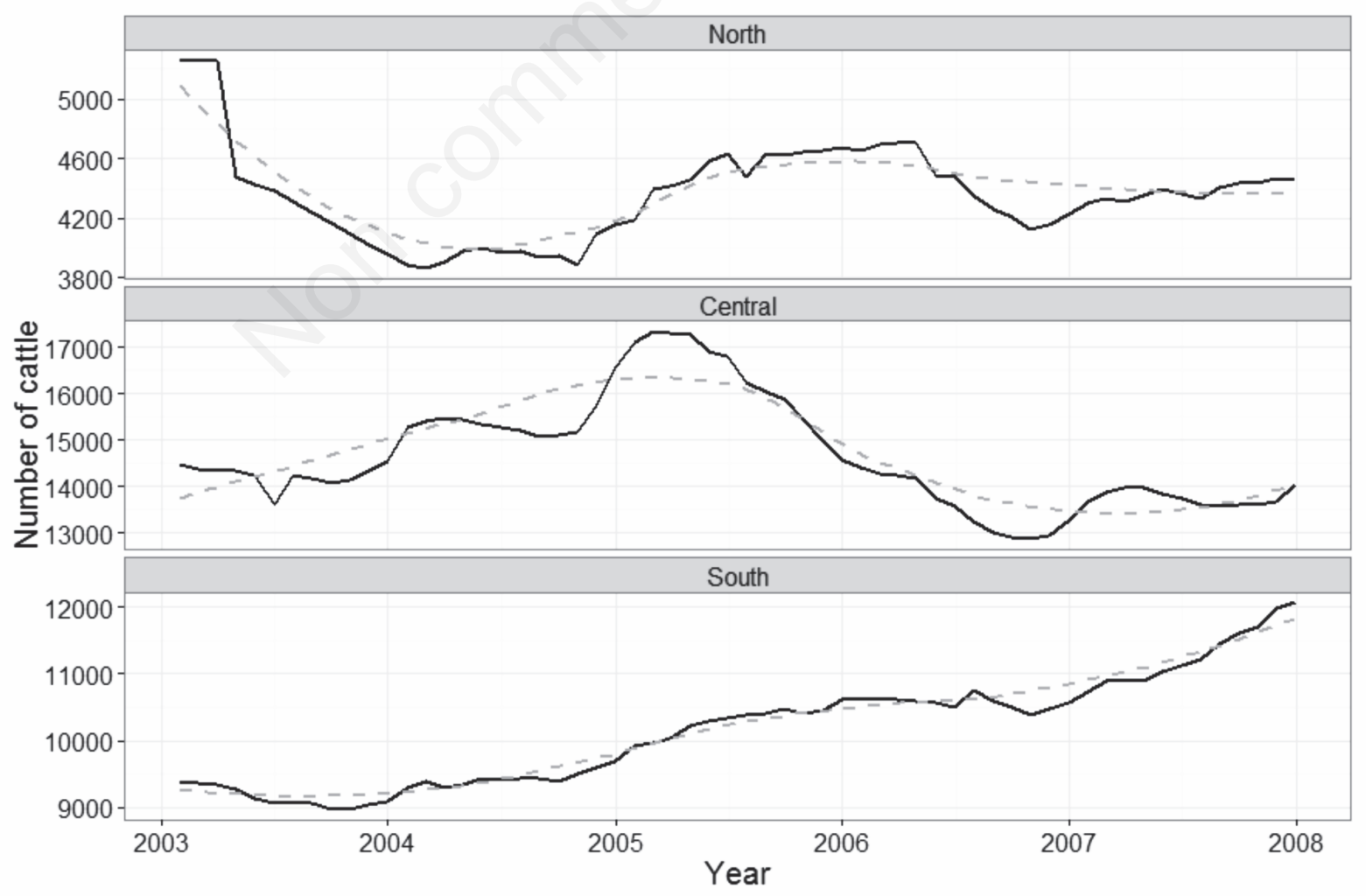

Figure 2. Total cattle numbers in each study site (temporal trend shown as a dashed line). 
icant in the northern site $(33.6 \%$, Pearson's product moment coefficient; $\mathrm{t}=2.34, \mathrm{P}<0.02)$.

\section{Owner ratio}

The median number of cattle owners in the northern, central and southern sites was 292 (280-295), 1150 (1122-1168) and 1282 (12701290 ), respectively. These numbers remained remarkably stable during the study period in comparison with the cattle numbers. The maximum fluctuation in the number of owners reached $20 \%$ in the North and Centre, while the southern site was more stable, recording a maximum fluctuation of only six percent. The median cattle/owner ratio in the North, Centre and South was 16.9 (12.7-21.9), 12.7 (11.2-14.0) and 8.1 (6.8-10.3), respectively, with a significant difference between the three study sites (Kruskal-Wallis rank sum test; $\mathrm{P}<0.01$ ). A significantly lower percentage of households own cattle in the South at $4.0 \%$ (2.4-4.6), compared to $13.7 \%(10.0-33.2)$ and $12.7 \%$ (9.3-15.1) in the North and Centre, respectively (Kruskal-Wallis rank sum test; $\mathrm{P}<0.01)$.

\section{Calves and calving patterns}

Calving peaked around December/January of each year with more than half (55.4\%) the annual calf crop born from November to the end of February (four months). The period between the beginning of June and the end of August (three months) had the lowest calving percent- ages, only producing $14.5 \%$ of the annual crop. This temporal pattern was more pronounced in the central site, where $62.9 \%$ of all calves were born from November to February.

A median annual calving rate per IP of $23.82 \%$ (17.19-29.91) was recorded for the entire study area. Although the calving rates varied between the years studied, there were no significant differences in annual calving rates between the study sites over the total study period, other than the significantly higher calving rate for the central site during the 2006/2007 years compared to the other two study sites (Kruskal-Wallis rank sum test, $\mathrm{P}<0.01$ ). Table 4 shows the calving rate and the Gini index outcome per study site for each year. It is noteworthy that the three peak calving months in all study sites over the four calving seasons were the same (January, December and February - in that order).

To assess the influence of rainfall and/or NDVI on conception rates, a cross-correlation analysis of the conception rate time series (log transformed) compared to the NDVI (mean) and rainfall (log transformed) time series was conducted. This revealed a significant relationship between conception rate and both these covariates $(\mathrm{P}<0.05)$ with both covariates leading conception in time, but displaying different time lags. Table 5 shows the lag between peak rainfal//NDVI and peak conceptions.

\section{Mortality}

Annual mortality rates recorded per IP for the northern, central and southern sites during the study period were $2.75 \%$ (1.61-4.06), $2.35 \%$

Table 4. Calving rate, median Gini index and top three calving months.

\begin{tabular}{|c|c|c|c|c|c|}
\hline & $2003 / 2004$ & $2004 / 2005$ & $2005 / 2006$ & $2006 / 2007$ & All years \\
\hline \multicolumn{6}{|l|}{ North } \\
\hline Calving rate & $\begin{array}{c}0.21 \\
(0.15-0.28)\end{array}$ & $\begin{array}{c}0.31 \\
(0.28-0.32)\end{array}$ & $\begin{array}{c}0.21 \\
(0.15-0.23)\end{array}$ & $\begin{array}{c}0.23 \\
(0.17-0.28)\end{array}$ & $\begin{array}{c}0.24 \\
(0.16-0.30)\end{array}$ \\
\hline Gini index & 0.39 & 0.51 & 0.63 & 0.57 & 0.53 \\
\hline Peak months & Mar, Jan, Feb & May, Feb, Jan & Jan, Dec, Feb & Jan, Dec, Nov & Jan, Dec, Feb \\
\hline \multicolumn{6}{|l|}{ Central } \\
\hline Calving rate & $\begin{array}{c}0.25 \\
(0.14-0.26)\end{array}$ & $\begin{array}{c}0.25 \\
(0.23-0.28)\end{array}$ & $\begin{array}{c}0.18 \\
(0.14-0.23)\end{array}$ & $\begin{array}{c}0.33 \\
(0.29-0.35)\end{array}$ & $\begin{array}{c}0.25 \\
(0.20-0.31)\end{array}$ \\
\hline Gini index & 0.46 & 0.62 & 0.55 & 0.55 & 0.55 \\
\hline Peak months & Jan, Nov, Dec & Dec, Jan, Nov & Dec, Feb, Jan & Jan, Dec, Feb & Jan, Dec, Feb \\
\hline \multicolumn{6}{|l|}{ South } \\
\hline Calving rate & $\begin{array}{c}0.22 \\
(0.18-0.28)\end{array}$ & $\begin{array}{c}0.27 \\
(0.20-0.42)\end{array}$ & $\begin{array}{c}0.21 \\
(0.11-0.27)\end{array}$ & $\begin{array}{c}0.22 \\
(0.18-0.25)\end{array}$ & $\begin{array}{c}0.23 \\
(0.17-0.28)\end{array}$ \\
\hline Gini index & 0.48 & 0.53 & 0.34 & 0.46 & 0.47 \\
\hline Peak months & Jan, May, Feb & Jan, Dec, Apr & Dec, Jan, Sep & Dec, Jan, Nov & Jan, Dec, Feb \\
\hline
\end{tabular}

Table 5. Time lag (months) between peak rainfall/normalised difference vegetation index and peak conceptions.

\begin{tabular}{|c|c|c|c|c|}
\hline \multicolumn{3}{|c|}{ Study site $\quad$ Rainfall } & \multicolumn{2}{|c|}{ NDVI } \\
\hline North & 3 & 0.44 & 2 & 0.60 \\
\hline Central & 2 & 0.65 & 0 & 0.64 \\
\hline South & 2 & 0.34 & 1 & 0.43 \\
\hline
\end{tabular}

NDVI, normalised difference vegetation index. 
(1.70-3.54) and 3.16\% (2.31-5.08), respectively. This was however highly variable from year to year, with the central site reporting a mortality rate of $14.42 \%$ (3.37-35.31) during 2005/2006. A space-time cluster analysis, using a discrete Poisson model, revealed a significant cluster of increased mortality (relative risk: 21.32 ; $\mathrm{P}<0.01$ ) in the northernmost six IPs of the central site for the period October 2005 to April 2006, while a secondary cluster (relative risk: 15.47; $\mathrm{P}<0.01$ ), spanning exactly the same period and completely overlapping the primary cluster, extended further north to include the entire northern site. Surprisingly, none of the concurrent NDVI or rainfall values for the affected IPs were significantly lower than those of the IPs outside either the clusters. However, rainfall and NDVI values from the previous season were significantly lower in these clusters than in the rest of the centre and all of the two other study sites $(\mathrm{P}<0.01$ for both clusters).

Another latitudinal gradient was observed in calf mortality, with the North recording significantly lower calf mortality than the other two study sites (Kruskal-Wallis rank sum test; $\mathrm{P}<0.01$ ). Actual numbers aggregated for the entire northern site over the four years, gave a remarkably low median calf mortality of $2.1 \%$, while at an IP level, across all years, three quarters of the reported annual calf mortality rates were below $2.9 \%$. This is in stark contrast to the South, where the median calf mortality per IP was $11.6 \%$ (5.2-21.4). In the central site, very high calf mortality was reported in 2005 and 2006 [14.6\% (6.3-21.3)] compared to the other three years studied [6.3\% (3.3$9.3)]$. The northern and southern sites did not show any particular temporal pattern in calf mortality within the years, while in the central site, the calf mortality was most concentrated in the short period between January and February (Gini index: 0.28).

While no significant relationship between cattle density and annual mortality (all age groups) was found, calf mortality did show a positive correlation with cattle density, even though it only accounted for $21 \%$ of the variation in calf mortality $\left(\mathrm{R}^{2}: 0.21 ; \mathrm{P}<0.01\right)$. Adding the negative correlation that calf mortality showed with cattle/owner ratio, explained $30 \%$ of the variation in calf mortality $\left(\mathrm{R}^{2}: 0.30 ; \mathrm{P}<0.01\right)$, whilst the same combination could explain very little of the variation in the annual mortality rates for the total population $\left(\mathrm{R}^{2}: 0.06\right.$, $\mathrm{P}<0.05)$. This effect was more pronounced in the South compared to the other study sites.

\section{Off-take}

The number of animals slaughtered as a percentage of the median number of animals per IP during the same time period, showed a significant difference between the North and the other two study sites, with annual slaughter percentages of $0.2 \%(0-1.4), 11.7 \%(9.2-16.5)$ and $11.0 \%$ (7.6-15.2) for the North, Centre and South, respectively (Kruskal-Wallis rank sum test; $\mathrm{P}<0.01$ ). Although no distinct temporal (monthly) pattern was detected in the slaughter behaviour of the IPs, the greatest number of animals slaughtered over the entire study period was reported in January (10.3\%). The highest Gini index was detected in the North (0.34), where slaughter peaked equally in January and April. Annually, and in relation to the median number of owners per IP, very low local meat consumption rates were observed in the North [0.04 cattle slaughtered per owner (0-0.16)], compared to the Central [1.6 (1.1-2.1)] and South [1 (0.6-1.1)] sites.

To get a better idea of the net movement of animals, as opposed to own/local consumption, we looked at the per-IP aggregated net permit movements per year, divided by the median number of owners at the same IP during the same period. Figure 3 clearly shows the tendency of owners to move cattle away from the IP in the North [-1 (-2.8 - $0.05)]$ and Centre [-0.4 (-1.2-0.1)], compared to the South [0.1 (-0.1-
0.4)], where owners were slightly more inclined to move animals towards the IP than away from it, i.e. buy or receive animals. In general, these permit movements and own/local consumption data indicate that owners from IPs in the North were 26 times more likely to move an animal away (selVgive) from the IP than to slaughter it locally. This contrasts with the central site, where an owner was four times more likely to slaughter an animal than move it away from the IP, and with the southern site, where an owner was twelve times more likely to slaughter one of his own animals than to move an animal towards the IP (buy/receive). Significant correlation $(\mathrm{P}<0.05)$ was found between slaughter and mortality in the central and southern sites. Cross-correlation analysis (Figure 4) showed that in the central site, slaughter and permit movements lead mortality rates by up to five months. In the South, slaughter and mortality peaked at the same time, or peak mortality preceded slaughter by one month. In the central site, at ten and twelve months after peak mortality, a significant influx of animals through permits occurred, possibly indicating some level of restocking. The northern site only showed a significant correlation at a lag period of three and five months, with mortality leading outgoing permit movements. The central site had the highest median net off-take rate at $16.09 \%(7.75-22.78)$, compared to the North at $7.23 \%(0.66$ $20.77)$ and the South at $8.43 \%$ (3.96-16.62). The median off-take rate across all sites and years was $10.8 \%$ (4.35-19.20). Some concentration of off-take occurred during the winter months, mostly in the North (Gini index: 0.31).

\section{Discussion}

In just over a decade, at our Southern site, the urban areas have increased by $39 \%$ since 1993 , resulting in both expanded as well as denser settlements with concomitant losses in natural vegetation and restriction of rangelands (Lambin et al., 2001; Coetzer et al., 2010; Herrero et al., 2010). The development poses a potential threat to the natural resource base that is crucial not just to subsistence livestock farming, but also to the many people whose livelihood depends on the area's wide range of natural products (Shackleton et al., 2001; Dovie et

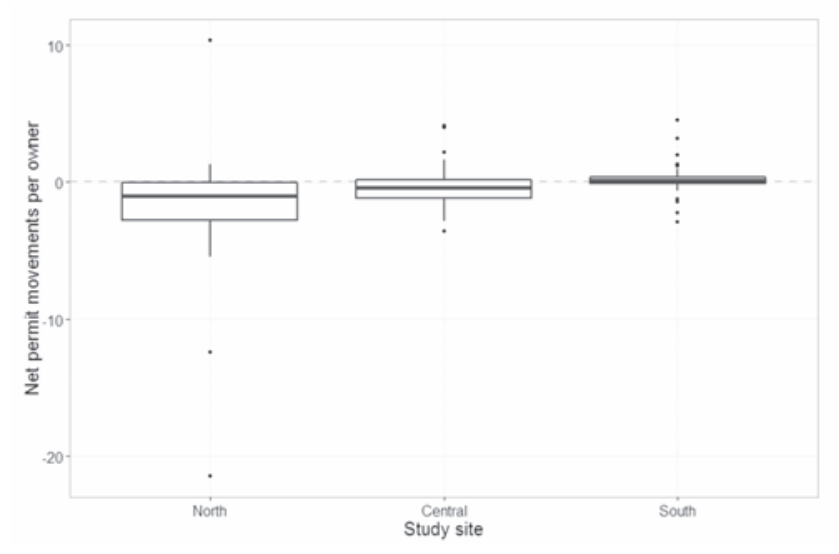

Figure 3. Net permit movements at livestock inspection points during the study period in each study site. 
al., 2003; Coetzer et al., 2010). This urban expansion was not necessarily a result of human population increase, which in fact decreased slightly over a similar period (Statistics South Africa, 2008). However, importantly, the cattle population in the southern site grew about five times more than the growth in the number of cattle owners during the same period. Notwithstanding, the increase of $168 \%$ in cattle had been reported previously for a six-year period in a specific village in Bushbuckridge (albeit a period immediately after the severe drought of 1992) (Dovie et al., 2006), which was similar to our findings, mainly due to an increase in herd size rather than numbers of livestock owners (Scogings et al., 1999; Shackleton et al., 2005). Herd accumulation in communal systems when optimal conditions prevail, may thus act as a form of insurance against adverse events (McPeak and Barrett, 2001).

The cattle densities we report (11.6-32.7 animals per $\mathrm{km}^{2}$ ), driven primarily by annual rainfall and human population density (Scoones, 1992b; Bourn and Wint, 1994; Wint and Robinson, 2007), fall within a similar range as reported elsewhere. However, we also found a positive correlation between cattle density and subsistence cultivation at a broad scale (across all study sites), which has been suggested as an important determinant of cattle distribution (Bourn and Wint, 1994; Wint and Robinson, 2007) through provision of post harvest supple- mentary fodder (Rocha et al., 1991; Düvel and Afful, 1996; Herrero et al., 2010). Regardless, no association between mortality or calving rates and the area of subsistence cultivation available (Mukhebi et al., 1991) could be detected in this study. The actual utilisation of crops as supplementary fodder appeared to be low as noted by Scoones (1992a) and Dovie et al. (2006) previously and buying of supplementary fodder was not common either.

Our approximation of the proportion of households owning cattle was lower than reported by others (Barrett, 1991; Shackleton et al., 2005; Moll, 2005; Dovie et al., 2006), especially in the South, where people appeared less inclined to practice agriculture compared to, for example, the northern site. Supporting evidence comes from the lower proportion of cattle-owning households, the smaller cattle to owner ratio, and the less than one third of a hectare of land cultivated per household. While this could be ascribed to other income generating opportunities in these highly populated areas in the South, it does not necessarily equate to a lower dependence on livestock (Shackleton $e t$ al., 2005; Dovie et al., 2006), especially when considering the much higher local meat consumption, most likely demand driven, in the South compared to the North. Concentrated or seasonal calving as a consequence of wet season conceptions that closely follow rainfall and NDVI increases, similar to what we observed, has been reported previ-

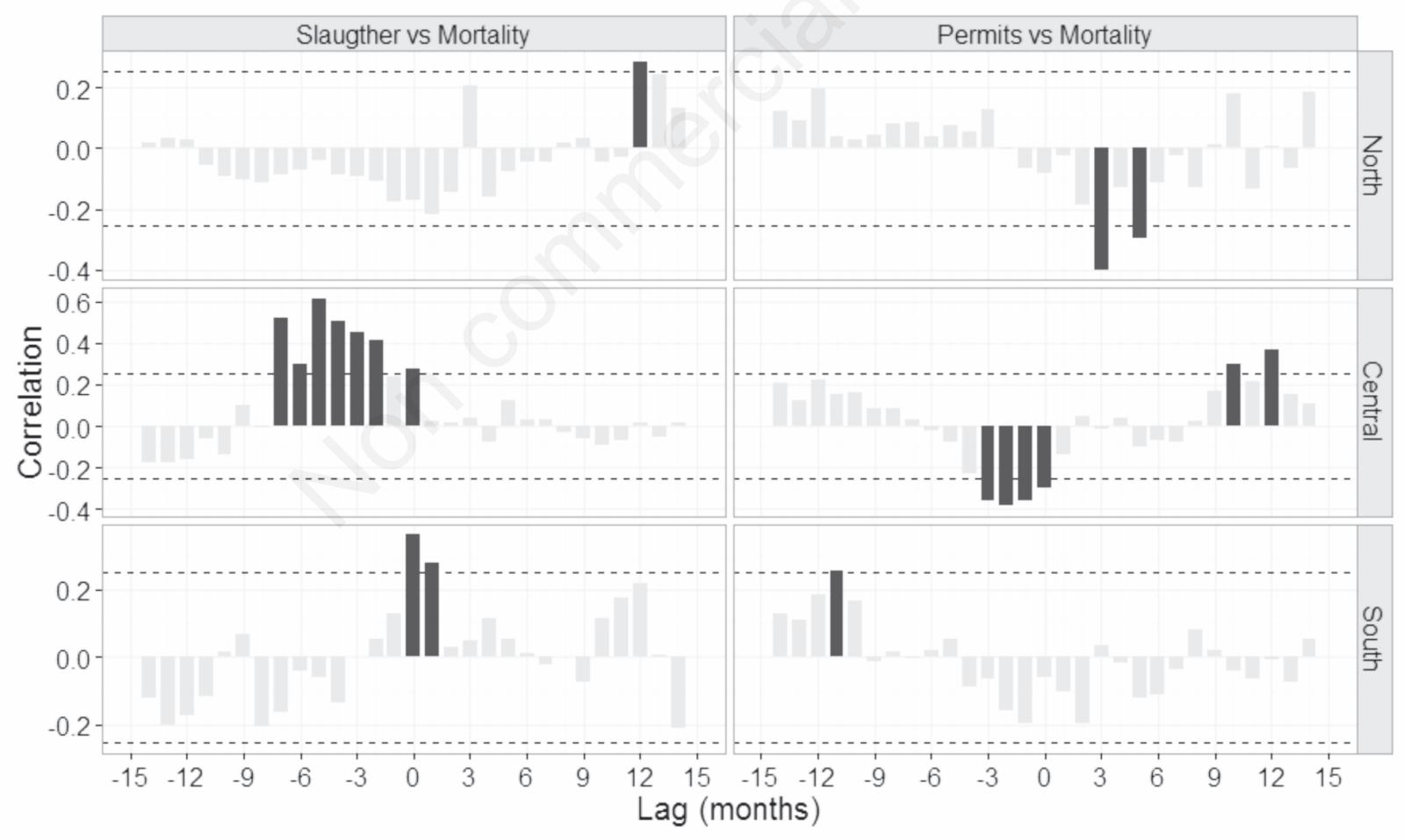

Significance $\square P<0.05 \quad P>0.05$

Figure 4. Cross-correlation between mortality and slaughter as well as net permit movements during the study period. A positive lag signifies mortalities leading to slaughter/permit movements. Outgoing permit movements were recorded as negative values and would thus result in negative cross-correlation values when outgoing permit movements predominated. Dashed horizontal lines signify the $\mathbf{9 5 \%}$ significance level with dark bars falling within this significance threshold. 
ously in cattle where no manipulation of reproduction occurs (Nqeno et al., 2010; Rocha et al., 1991). A poor conception year followed by a higher than normal one, e.g. in the Centre during 2006/2007, a phenomenon previously described (Scoones, 1992a), is most likely related to the number of cows that are not pregnant or lactating following a low conception year and consequently not available for mating during the following year. This comes at a potential cost, since highly fertile cows that do conceive during these difficult years often succumb due to the nutritional strain demanded by pregnancy or lactation, a situation that effectively selects against higher fertility (Moyo, 1996; Swanepoel et al., 2000; Desta and Coppock, 2002; Stroebel, 2004; Stroebel et al., 2008). Since our calving rates are based on the entire herd, not just the cows, it is difficult to compare our results directly to comparable figures published, although studies in areas similar to our study sites suggest that the cow proportion of herds is approximately 50\% (Swanepoel et al., 2000; Shackleton et al., 2005; Stroebel et al., 2011). If so, our calving rates are very similar to what others have reported in communal herds (Behnke Jr., 1985; Rocha et al., 1991; Nthakheni, 2006; Angassa and Oba, 2007; Ba et al., 2011). A 50\% calving rate, suggesting an average of one calf per cow every two years, is quite good in reproductive terms, especially considering the general lack of forced weaning (Rocha et al., 1991) and the low number of farmers who provide supplementary feed (Scoones, 1992a; Dovie et al., 2006). We were however unable to quantify embryonic loss, abortion or stillbirths; neither could we directly estimate the role of disease, if any, in reproduction. Studies in the vicinity of our central and northern sites have reported $20-23 \%$ calves in the population with lower proportions observed in drier years (Swanepoel et al., 2000; Mahabile et al., 2005, Stroebel et al., 2011), which is similar to our findings in the central site.

The annual mortality rates reported in the three study sites were relatively low (0-16\%) compared to those reported in the literature (030\%) (Rocha et al., 1991; Scoones, 1992b; Shackleton et al., 2005). Even though we did not experience any drought during the study (which can cause mortality rates up to 70\%; (Mukhebi et al., 1991; Moyo, 1996; Swanepoel et al., 2000; Barrett, 2001; Desta and Coppock, 2002; McPeak and Barrett, 2001), the significant relationship between elevated mortality and the previous season's rainfall/NDVI, rather than that of the concurrent season, was an interesting finding. Obviously, mortality does not follow a linear relationship with precipitation and NDVI (as proxy for available fodder), but the animals are rather pushed to the brink of their nutritional resilience (Desta and Coppock, 2002; Angassa and Oba, 2007) as a longer-term consequence of these factors. Although the majority of mortality cases can generally be attributed to poor nutrition, especially during dry periods (Rocha et al., 1991; Desta and Coppock, 2002; Shackleton et al., 2005), we cannot answer this question, as our data did not distinguish between nutritional and disease-related mortality. Since we could not quantify stock theft (which is also recorded as mortality), it is important to keep it in mind as a confounder of reported mortality figures, especially in the more densely populated areas, where it is increasing (Rocha et al., 1991; Ainslie et al., 2002; Shackleton et al., 2005).

A similar positive correlation between cattle as well as human density and calf mortality found in this study has been reported before (Lybbert et al., 2004). These authors further reported a negative correlation between herd size and calf mortality, which concurs at an IP level. These phenomena could stem from competition for milk, both with other calves and with humans (Wilson and Clarke, 1976; Cossins and Upton, 1987), especially in the densely populated areas with limited grazing areas, such as in the southern site.

Off-take rates recorded during our study are slightly elevated when compared with other studies (Mukhebi et al., 1991; Rocha et al., 1991; Scoones, 1992b; Swanepoel et al., 2000; Shackleton et al., 2005; Mahabile et al., 2005; Stroebel et al., 2011). In the South, where there is high local demand, slaughter rates were correspondingly high; however, the off-take often surpassed what natural production could replace, hence the net import of animals to IPs observed there. This high off-take rate is further exacerbated by small herd sizes and high calf mortality. The high proportion of meat consumption by the owners of small herds in densely populated areas, which is not unexpected (Mukhebi et al., 1991), might be regarded as an encouraging increase of the integration of livestock into local markets (Jones and Thornton, 2009). In the North, off-take was dominated by movement of animals away from the IP, with local slaughter rates very low and peaking close to the Christmas/New Year period, start of the first school term and the Easter holidays, which might indicate some level of market intelligence. In the Centre, on the other hand, local consumption was sufficiently low in relation to natural production to allow movements away from the IPs as an additional off-take strategy. The central site had the highest off-take rate of the three study sites, confirming that overall the rates are not necessarily the highest in areas with the largest herds (Musemwa et al., 2008; Ba et al., 2011). Our findings are most likely explained by the general lack of local markets in combination with the inverse relation between herd size and human density, limiting local opportunities to sell or slaughter for those owners with bigger herds. However, our findings of a general inverse association between movements/sales (i.e. not local/own consumption) and rainfall, concur with the findings of others (Shackleton et al., 2005).

A great variety of responses of livestock owners to adverse conditions, such as increased slaughter, increased and decreased sales, increased movements, reduction in herd size and even complete destocking have been reported in a number of communal areas in the past (Scoones, 1992a; McPeak, 2004, Shackleton et al., 2005). What is noteworthy in this study is the apparent proactive risk aversion strategy of owners in the Centre, which occurred both through slaughter and movements away from IPs a number of months before mortality peaked during an extended dry period as well as ostensible restocking through increased importation of animals in the more favourable months that followed. In the South, on the other hand, the timing of the response to increased mortality rates seemed to be more a case of salvage (or distress) slaughter than risk aversion, possibly because the smaller herd sizes in this study site did not allow large-scale preemptive sales/slaughter without complete, or near-complete, destocking. Surprisingly, the northern site seemed almost indifferent towards anticipated mortality, which might be a consequence of their larger herds that could buffer losses, as well as the low demand for meat from local slaughter. Off-take through (non-local) sales is not a simple matter in these study sites, especially considering the lack of commercial abattoirs or feedlots as well as the distances involved in travelling to sell cattle, often for only a few animals (Musemwa et al., 2008). Although very low levels of competition often leads to poor prices, this problem is frequently overcome through speculators and auctions; hence the tendency to sell locally when demand allows it (Nkhori, 2004).

From the disease risk perspective, the sloping cattle density gradient from north to south is notable, especially where direct contact with FMD must be considered, both from a likelihood of interaction with buffaloes as well as cattle to cattle spread. Also, the seasonality of calving is useful in prospectively determining the period at which most young animals would be losing their maternal immunity and would be most susceptible to disease. This is helpful in the spatio-temporal risk profiling as well as the implementation of vaccination programmes, 
especially in the case of FMD, where buffaloes and cattle tend to show very similar seasonality in their calving patterns (Ryan et al., 2007) with possible linkages between young animals and infectivity (Bengis et al., 1986; Thomson, 1996; Vosloo et al., 2005). Furthermore, off-take strategies could influence disease spread, especially over larger distances, while local meat consumption patterns could influence zoonotic disease risk.

\section{Conclusions}

The findings we present here clearly show that a great deal of heterogeneity exists in the communal livestock component of the KNP and APNR wildlife-livestock-human interface, not only in its physical attributes, but also in the way people and animals respond to, and interact with, these attributes and each other. Such activities are important to consider, especially in disease control strategies and disease risk assessments, where they are often oversimplified or unknowingly ignored due to their indirect nature. While a number of findings could be broken down to show more details, they already increase our insight into how this unique system operates enabling us to employ risk assessment and control strategies that not only are more effective from a disease prevention point of view, but also have the least possible negative impact on the system itself.

\section{References}

Abel N, 1997. Mis-measurement of the productivity and sustainability of African communal rangelands: a case study and some principles from Botswana. Ecol Econ 23:113-33.

Ainslie A, Kepe T, Ntsebeza L, Ntshona Z, Turner S, 2002. Programme for land and agrarian studies: cattle ownership and production in the communal areas of the Eastern Cape, South Africa. University of the Western Cape, Bellville, Cape Town. Available from: http://www.plaas.org.za/sites/default/files/publicationspdf/RR10.pdf

Angassa A, Oba G, 2007. Relating long-term rainfall variability to cattle population dynamics in communal rangelands and a government ranch in southern Ethiopia. Agric Syst 94:715-25.

Ba A, Lesnoff M, Poccard-Chapuis R, Moulin CH, 2011. Demographic dynamics and off-take of cattle herds in southern Mali. Trop Anim Health Pro 43:1101-9.

Barrett JC, 1991. Pastoral development network papers: the economic role of cattle in communal farming systems in Zimbabwe. Overseas Development Institute, London, UK.

Behnke Jr RH, 1985. Measuring the benefits of subsistence vs commercial livestock production in Africa. Agric Syst 16:109-35.

Behnke Jr RH, 1987. Cattle accumulation and the commercialization of the traditional livestock industry in Botswana. Agric Syst 24:129.

Bengis RG, Thomson GR, Hedger RS, De Vos V, Pini A, 1986. Foot-andmouth disease and the African buffalo (Syncerus caffer). 1. Carriers as a source of infection for cattle. Onderstepoort $\mathrm{J}$ Vet Res 53:69-73.

Beyer HL, 2004. Hawth's analysis tools for ArcGIS. Version: 3.27. Available from: http://www.spatialecology.com/htools

Bourn D, Wint W, 1994. Pastoral development network papers: livestock, land use and agricultural intensification in Sub-Saharan
Africa. Overseas Development Institute, London, UK.

Brückner GK, Vosloo W, Du Plessis BJA, Kloeck PELG, Connoway L, Ekron MD, Weaver DB, Dickason CJ, Schreuder FJ, Marais T, Mogajane ME, 2002. Foot and mouth disease: the experience of South Africa. Available from: www.oie.int/doc/ged/d497.pdf

Carroll ML, DiMiceli CM, Sohlberg RA, Townshend JRG, 2004. 250m MODIS normalized difference vegetation index. University of Maryland, College Park, MA, USA.

Coetzer KL, Erasmus BFN, Witkowski ETF, Bachoo AK, 2010. Landcover change in the Kruger to Canyons Biosphere Reserve (19932006): a first step towards creating a conservation plan for the subregion. S Afr J Sci 106:1-10.

Cossins NJ, Upton M, 1987. The Borana pastoral system of Southern Ethiopia. Agric Syst 25:199-218.

Cowpertwait PSP, Metcalfe AV, 2009. Introductory time series with R. Springer-Verlag, New York, NY, USA.

Desta S, Coppock DL, 2002. Cattle population dynamics in the southern Ethiopian rangelands, 1980-97. J Range Manage 55:439-51.

Dovie DBK, Shackleton CM, Witkowski ETF, 2006. Valuation of communal area livestock benefits, rural livelihoods and related policy issues. Land Use Policy 23:260-71.

Dovie DBK, Witkowski ETF, Shackleton CM, 2003. Direct-use value of smallholder crop production in a semi-arid rural South African village. Agric Syst 76:337-57.

Düvel GH, Afful DB, 1996. Sociocultural constraints on sustainable cattle production in some communal areas of South Africa. Development Southern Africa 13:429-40.

Eastman JR, 2006. Idrisi Andes. Clark University, Worcester, MA, USA. ESRI, 2009. Available from: http://www.esri.com/

Gastwirth JL, 1972. The estimation of the Lorenz curve and Gini index. Rev Econ Stat 54:306-16.

GeoterraImage, 2008. Land-cover classification for peace parks foundation: Greater Limpopo Transfrontier Park priority plus Banhine plus Kruger National Park (West) dataset. GeoterraImage (Pty) Ltd, Pretoria, South Africa.

Giannecchini M, Twine W, Vogel C, 2007. Land-cover change and human-environment interactions in a rural cultural landscape in South Africa. Geogr J 173:26-42.

Goqwana WM, Machingura C, Mdlulwa Z, Mkhari R, Mmolaeng 0, Selomane A0, 2008. A facilitated process towards finding options for improved livestock production in the communal areas of Sterkspruit in the Eastern Cape province, South Africa. Afr J Range Forage Sci 25:63-9.

Herrero M, Thornton PK, Gerber P, van der Zijpp A, van de Steeg J, Notenbaert AM, Lecomte P, Tarawali S, Grace D, 2010. The way forward for livestock and the environment. In: Swanepoel F, Stroebel A, Moyo S, eds. The role of livestock in developing communities: enhancing multifunctionality. University of the Free State and CTA, Cape Town, South Africa, pp 51-76.

Hijmans RJ, Cameron SE, Parra JL, Jones PG, Jarvis A, 2005. Very high resolution interpolated climate surfaces for global land areas. Int J Climatol 25:1965-78.

Jones PG, Thornton PK, 2009. Croppers to livestock keepers: livelihood transitions to 2050 in Africa due to climate change. Environ Sci 12:427-37.

Joubert S, 2007. The era 1946 to 1960. In: Joubert S, ed. The Kruger National Park: a history. High Branching (Pty) Ltd, Johannesburg, South Africa. Available from: http://www.thekruger.com/stories/ history_of_kruger_plant_life.htm

Kirsten JF, Moldenhauer W, 2006. Measurement and analysis of rural household income in a dualistic economy: the case of South 
Africa. Agrekon 45:60-77.

Klingseisen B, Stevenson M, Corner R, 2013. Prediction of Bluetongue virus seropositivity on pastoral properties in northern Australia using remotely sensed bioclimatic variables. Prev Vet Med 110:159-68.

Kulldorff M, 1997. A spatial scan statistic. Commun Stat Theory Methods 26:1481-96.

Lambin EF, Turner BL, Geist HJ, Agbola SB, Angelsen A, Bruce JW, Coomes OT, Dirzo R, Fischer G, Folke C, George PS, Homewood K, Imbernon J, Leemans R, Li X, Moran EF, Mortimore M, Ramakrishnan PS, Richards JF, Skånes H, Steffen W, Stone GD, Svedin U, Veldkamp TA, Vogel C, Xu J, 2001. The causes of landuse and land-cover change: moving beyond the myths. Global Environ Change 11:261-9.

Lee WC, 1996. Analysis of seasonal data using the Lorenz curve and the associated Gini Index. Int J Epidemiol 25:426-34.

Lybbert TJ, Barrett CB, Desta S, Coppock DL, 2004. Stochastic wealth dynamics and risk management among a poor population. Econ $\mathrm{J}$ 114:750-77.

Mahabile M, Lyne MC, Panin A, 2005. An empirical analysis of factors affecting the productivity of livestock in southern Botswana. Agrekon 44:99-117.

Mapiye C, Chimonyo M, Dzama K, 2009a. Seasonal dynamics, production potential and efficiency of cattle in the sweet and sour communal rangelands in South Africa. J Arid Environ 73:529-36.

McPeak J, 2004. Contrasting income shocks with asset shocks: livestock sales in northern Kenya. Oxford Econ Pap 56:263-84.

McPeak JG, Barrett CB, 2001. Differential risk exposure and stochastic poverty traps among East African pastoralists. Am J Agr Econ 83:674-9.

Moll HAJ, 2005. Costs and benefits of livestock systems and the role of market and nonmarket relationships. Agr Econ 32:181-93.

Moyo S, 1996. The productivity of indigenous and exotic beef breeds and their crosses at Matopos, Zimbabwe. PhD Thesis. University of Pretoria, Pretoria, South Africa.

Mukhebi AW, Knipscheer HC, Sullivan G, 1991. The impact of foodcrop production on sustained livestock production in semi-arid regions of Kenya. Agric Syst 35:339-51.

Musemwa L, Mushunje A, Chimonyo M, Fraser G, Mapiye C, Muchenje $\mathrm{V}, 2008$. Nguni cattle marketing constraints and opportunities in the communal areas of South Africa: review. Afr J Agric Res 3:23945.

Nkhori PA, 2004. The impact of transaction costs on the choice of cattle markets in Mahalapye District, Botswana. MSc thesis. University of Pretoria, Pretoria, South Africa: Available from: repository.up.ac.za/bitstream/handle/2263/26363/00dissertation.p df? sequence $=1$ \&isAllowed $=y$

Nqeno N, Chimonyo M, Mapiye C, Marufu MC, 2010. Ovarian activity, conception and pregnancy patterns of cows in the semiarid communal rangelands in the Eastern Cape Province of South Africa. Anim Reprod Sci 118:140-7.

Nthakheni ND, 2006. A livestock production systems study amongst resource-poor livestock owners in the Vhembe District of Limpopo Province. PhD Thesis. University of the Free State, Bloemfontein, South Africa.

R Core Team, 2013. R: a language and environment for statistical computing. Version: 2.13. R Foundation for Statistical Computing, Vienna, Austria.

Randolph TF, Schelling E, Grace D, Nicholson CF, Leroy JL, Cole DC, Demment MW, Omore A, Zinsstag J, Ruel M, 2007. Invited review: role of livestock in human nutrition and health for poverty reduc- tion in developing countries. J Anim Sci 85:2788-800.

Rocha A, Starkey P, Dionisio AC, 1991. Cattle production and utilisation in smallholder farming systems in Southern Mozambique. Agric Syst 37,:55-75.

Ryan SJ, Knechtel CU, Getz WM, 2007. Ecological cues, gestation length, and birth timing in African buffalo (Syncerus caffer). Behav Ecol 18:635-44.

Scharlemann JPW, Benz D, Hay SI, Purse BV, Tatem AJ, Wint GRW, Rogers DJ, 2008. Global data for ecology and epidemiology: a novel algorithm for temporal fourier processing MODIS data. PLoS One 3:e1408.

Scogings P, de Bruyn T, Vetter S, 1999. Grazing into the future: Policy making for South African communal rangelands. Dev South Afr 16:403-14.

Scoones I, Bishi A, Mapitse N, Moerane R, Penrith ML, Sibanda R, Thomson G, Wolmer W, 2010. Foot-and-mouth disease and market access: challenges for the beef industry in southern Africa. Pastoralism 1:135-64.

Scoones I, 1992a. Coping with drought: responses of herders and livestock in contrasting Savanna environments in southern Zimbabwe. Hum Ecol 20:293-314.

Scoones I, 1992b. The economic value of livestock in the communal areas of southern Zimbabwe. Agric Syst 39:339-59.

Shackleton CM, Shackleton SE, Cousins B, 2001. The role of landbased strategies in rural livelihoods: the contribution of arable production, animal husbandry and natural resource harvesting in communal areas in South Africa. Dev South Afr 18:581-604.

Shackleton CM, Shackleton SE, Netshiluvhi TR, Mathabela FR, 2005. The contribution and direct-use value of livestock to rural livelihoods in the Sand River catchment, South Africa. Afr J Range Forage Sci 22:127-40.

Statistics South Africa, 2001. Census 2001: small area statistics. Statistics South Africa, Pretoria, South Africa.

Statistics South Africa, 2008. Community survey 2007: statistical release basic results municipalities. Statistics South Africa, Pretoria, South Africa.

Stroebel A, 2004. Socio-economic complexities of smallholder resource-poor ruminant livestock production systems in SubSaharan Africa. PhD Thesis. University of the Free State, Bloemfontein, South Africa.

Stroebel A, Swanepoel FJC, Nthakheni ND, Nesamvuni AE, Taylor G, 2008. Benefits obtained from cattle by smallholder farmers: a case study of Limpopo Province, South Africa. Aust J Exp Agric 48:8258.

Stroebel A, Swanepoel FJC, Pell AN, 2011. Sustainable smallholder livestock systems: a case study of Limpopo Province, South Africa. Livest Sci 139:186-90.

Swanepoel FJC, Stroebel A, Nthakheni D, 2000. Productivity measures in small-holder livestock production systems and social development in southern Africa. Asian-Aus J Anim Sci 13:321-4.

Thomson GR, 1996. Foot and mouth disease in the African buffalo. In: Penzhorn BL, ed. African buffalo as a game ranch animal. University of Pretoria, Pretoria, South Africa, pp 113-6.

Vandamme E, D’Haese M, Speelman S, D'Haese L, 2010. Livestock against risk and vulnerability: multifunctionality of livestock keeping in Burundi. In: Swanepoel F, Stroebel A, Moyo S, eds. The role of livestock in developing communities: enhancing multifunctionality. University of the Free State and CTA, Cape Town, South Africa, pp 106-121.

Van Schlalkwyk OL, 2015. A spatio-temporal probability model of cattle and African buffalo (Syncerus caffer) contact as a proxy for foot- 
and-mouth disease risk: a case study at the wildlife-livestock interface of the Kruger National Park, South Africa. PhD Thesis. University of Pretoria, Pretoria, South Africa.

Vosloo W, Bastos ADS, Boshoff CI, 2006. Retrospective genetic analysis of SAT-1 type foot-and-mouth disease outbreaks in southern Africa. Arch Virol 151:285-98.

Vosloo W, Bastos ADS, Sahle M, Sangare 0, Dwarka RM, 2005. Virus topotypes and the role of wildlife in foot and mouth disease in Africa. In: Osofsky SA, Cleaveland S, Karesh WB, Kock MD, Nyhus PJ, Starr L, Yang A, eds. Conservation and development interventions at the wildlifelivestock interface: implications for wildlife, livestock and human health. IUCN - The World Conservation
Union, Gland, Switzerland, pp 67-74.

Vosloo W, Bastos ADS, Sangare 0, Hargreaves SK, Thomson GR, 2002. Review of the status and control of foot and mouth disease in subSaharan Africa. Available from: http://web.oie.int/boutique/ extrait/11vosloo.pdf

Wilson RT, Clarke SE, 1976. Studies on the livestock of Southern Darfur, Sudan. II. Production traits in cattle. Trop Anim Health Pro 8:47-57.

Wint GRW, Robinson TP, 2007. Gridded livestock of the world 2007. Food and Agriculture Organization, Rome, Italy. Available from: ftp://ftp.fao.org/docrep/fao/010/a1259e/a1259e00.pdf 